\title{
The Influence of Suggested Cornell Note-taking Method on Improving Writing Composition Skills of Jordanian EFL Learners
}

\author{
Mohammad Akram Alzu'bi \\ English Department, Ajloun University College, Al-Balqa Applied University, Jordan
}

\begin{abstract}
The study aimed at discovering the impact of suggested Cornell Note-Taking Training Model on improving writing composition skills. The sample of the study consisted of (58) English students in the second year selected randomly from the English departments in Al-Balqa Applied university. The sample was divided into two groups: experimental and control group. The researcher designed an exam and examined the students in both groups in pre-test and post-test to find the equivilance and the difference between both groups. After examination and analyzing data, the results of the study show statistical significant differences at the significance level $(\alpha \leq \mathbf{0 . 0 5})$ between the mean scores of the experimental group which taghut by using Cornell method and the control group which used the conventional method in teaching composition.
\end{abstract}

Index Terms - Cornell note-taking method, composition writing skills, EFL learners

\section{INTRODUCTION}

Many specialists have defined writing in different ways, for example, Daniels \& Bright (1996) defined it as a system of more or less permanent marks used to represent an utterance in such a way that it can be recovered more or less exactly without the intervention of the utterer. According to (Nunan, 2003), writing is physical and mental act to develop ideas into paragraphs and it is a process which is created by the writers and also a product which is read by audience for communication. However, none of them defined it perfectly to cover all of its systems, and most of them share the same items. Therefore, the researcher suggested that writing skill is a method that includes sets of visual symbols for representing spoken language in visual form for the purpose of communication.

Writing should be graded from the easiest parts to more complicated ones so before learning how to write composition, students should learn how to write paragraphs. Bani Yaseen (2010) focused on adopting before-writing skills and gradation to fulfill the different purposes of witing at every age period regardless of types of writing. Unfortunately, most Jordanian school and university students face problems with the skills of writing composition such as difficulties in using processes of planning, construction, and revision. Moreover, the time of the writing lessons is limited, so it is difficult for the students to realize the important information to write down and how to organize in order to write after the class time. In the past, Nakkash (1978) claimed that most of the difficulties in writing composition come from the necessary information and the ability to arrange them in a suitable order. Out of his experience, the researcher has found that students have problems with adopting the stages of writing composition (pre-writing, whilewriting, and post-writing), although they have studied the elements of writing composition theoretically.

When the researcher contacted his students who studied the advanced writing course personally, they complained about the methods of learning how to write composition at school; teachers only gave them feedback in examinations without applying helpful strategies at the time of writing composition about any topic. Trying to find solutions for the above mentioned problems of writing composition, the researcher suggests that instructors and teachers should use useful methods in teaching writing. Thus, to learn how to write composition effectively, students need to adopt specific methods to help them in writing composition and essays. As a result, the researcher selected Cornell method because of its advantages in improving students' studying in general and it might improve the skills of writing composition in particular. Cornell method is an essencial method to organize information and record the information (William, 2004)

Since most studies have found that using Cornell method in English language learning class was effective in most subjects especially in learning listening comprehension, the researcher conducted the present study to find out wheather Cornell Method helps improve writing composition skills of Jordanian EFL Learners and solves their problems in writing composition.

\section{A. Statement of the Problem}

Based on his teaching experience in universities at English department, the researcher has noticed that most students get low marks in writing courses because they face difficulties in writing; for example; they don't understand new words and they couldn't either use them properly in writings. In his experience as a language lecturer, the researcher has also noticed that many students write without employing suitable strategies for remembering and organizing the material presented in the class, and they forget a lot of information while learning paragraph or essay Writing classes. 
Finally, students do not use the all three stages of writing while writing composition or paragraph; for example, most of them do not use the pre-stage or post-stage correctly in the writing process so they need a useful method to solve all above mentioned problems. The researcher found that Cornell method is the most suitable to improve writing composition because of its nature and characteristics so the researcher conducted the study to find the effect of suggested Cornell method on improving writing composition.

\section{B. The Importance of the Study}

It is believed that this study is considered as an important related study for many researchers and writers in the future because the researcher rebuilds Cornell method to be suitable and effective in writing composition since the present study introduces a practical model in writing instead of theory. In addition, the study provides a prepared training program, reliable instruments, active procedures, and experimental findings to be employed in future research.

\section{The Purpose of the Study}

The main purpose of the study is to measure the effect of Cornell method on improving composition writing by answering the following main question:

What is the effect of Cornell method on improving the skills of writing composition?

\section{The Operational Definitions of Terms}

Cornell Method is a note-taking format designed by Walter Pauk which involves a card to record main ideas, supporting details, and summaries as shown in Appendix A (Pauk \& Owens, 2011).

Suggested Cornell method is a method for taking notes that designed by the researcher according to the note-taking card which designed of Walter Pauk. The card is redesigned according to the three stages of writing (pre-reading, whilereading and post-reading) and elements of composition to help English students at Jordanian universities learn how to write composition.

Writing achievement is the scores of the students in the post-test of composition.

\section{E. Limitation of the Study}

The current study is limited by the participants of the study who studied English as a forighn language (EFL) in AlBalqa Applied University. Also, it is limited by the suggested program which based on Cornell method designed by the researcher and confined to writing composition elements.

\section{LITERATURE REVIEW}

\section{A. Theoretical Framework and Related Studies}

Cornell method was developed by Pauk 1974 in order to help students in Cornell University to organize, record and receive notes. It uses a card of three sections (see appindix 1); the right column for recording the lecturs ideas, the left column (cue column) to fill questions and outlines in later and the third section which is at the bottom of the card for summarizing and evaluating (Pauk, 2011, Pp. 237-238).

Cornell method was derived from the cognitive psychology which focuses on information processing that affects data storage in the-long term memory. Lieberman (2000) claimed that information processing comprised of three stages; the sensory memory, the short-term memory and the long-term memory. The first stage which takes place in the sensory memory recieves the information and transfers them to the short-term memory (working memory). The second part is the working memory which can hold limited information for limited time and it transfers the information to the third memory which is the long-term memory if there is no interference and stored until it is needed.

\section{B. Related Studies}

The literature review arranged in a systemetic way, the first part handled the influence of note-taking strategies on students' listening comprehension as well as their writing skills as follows:

Few studies are conducted about the effect of using note-taking on the first (L1) and second language (L2) because teachers and researchers do not pay enough attention to investigating issues related to the effect of note-taking on improving the language skills or about note-taking and second language learning in general (Chaudron, Loschky, \& Cook, 1994; Clerehan, 1995; Famhy \& Bilton, 1991). Moreover, no studies are conducted about the effect of Cornell method on writing but there is a study examined the effect of note-taking in general on writing which was invistigated by (Al-Ashkar, 2014). One of its results showed that note-taking improved writing skill. However, the researcher has mentioned some studies about the effect of using different strategies of note-taking on achievement in general and language skills and its components.

Firstly, three studies were conducted about the effect of Cornell method on improving achievement in general; the first study was conducted by (Jacobs, 2008) which aimed at reviewing some studies about the effect of note-taking methods on 58 English students' performance. After reviewing, the researcher used the same tests on the students and found that the Cornell method was useful, although the students who used the guided notes method showed a showed better achievement than the Cornell group. The second study conducted by (Zorn, 2017) showed a positive improvement using the Cornell method to improve students' achievement. 
Cornell method not only has positive influance on normal students, but also it is effective on students with disabilities. For example, Baharev (2016)carried out a study that compare students with and without disabilities at sixty eighth grade who learned by using note-taking using Cornell method with those who learned by using lecture method. The results of the study indicated that note-taking strategy improved the student's performance.

Secondly, the researcher found three studies that were conducted about the effect of using Cornell method on English language skills such as grammar and listining. The first study (Davoudi, Moattarian \& Zareian, 2015) aimed at finding the effect of Cornell Method on Grammar. The researchers selected seventy intermediate Iranian EFL students (44 males and 26 females) and distributed them to two groups. After giving both groups a pre-test to make sure that both groups are equilvilant, the experimental group was trained by using Cornell method in learning grammar. After administrating post-test to both groups to find the differences between them, the researchers analyzed the obtained data by using T-tests to find out if Cornell method affects learning grammar positively or negatively. The results of the study indicated that the Cornell method improved grammatical knowledge and critical thinking. In the other studies (Rahmani \& Sadeghi, 2011\& Hayati, 2009) examined the impact of note-taking technique on improving the listening skill. The first study examined the effect of note-taking on Iranian EFL learners' comprehension. The sample of the study consisted of 108 students who were assigned to experimental and control groups; the experimental group consisted of 48 students and the control group which included 60 students. The researchers trained the experimental group by using note-taking "graphic organizers", while the conventional group did not receive any instruction. The researchers used two multiple-choice reading tests to measure note-taking effectiveness. The findings of the study indicated that students who used graphic organizers performed better rather than students who studied by using the conventional method. The second study (Hayati, 2009) selected a sample in his study that consisted of sixty undergraduate students, majoring in English at Shahid Chamran University of Ahvaz to find out if note-taking strategies improve listening comprehension. The researcher divided the sample into three groups and one of them is taught by Cornell method. The results of the study revealed that there were significant differences while using Cornell method so it affects positively on listening skill.

Althogh the results of all previous studies approved the positive effects of note-taking strategies like Cornell method on students' achievement, (Borr, et al., 2012) conducted a study to find the effect of the Cornell method on student's performance and he concluded that there was no significant difference in Cornell note-taking on student performance. The researcher discussed his results and justified the result by saying that "Cornell note-taking is a method for organizing notes and there was no way to know if students were actually using the notes for study purposes."

Respecting Jordanian context, no studies have been found about the influence of using Cornell method in an English classroom environment, particularly in writing. The present study was conducted to achieve this aim while providing valuable insights for language teachers and learners.

\section{The Methods AND PROCEDURES}

\section{A. Study Subjects}

The sample of the study consists of fifty-eight students from two classes of "writing composition course": One class is considered as an experimental group; and the other class as the control group. This sample depends on the distribution of the Registration Department at Ajloun University College in Al-Balqa' Applied University, Jordan. The treatment's period takes one semester (The $1^{\text {st }}$ semester, 2019).

\section{B. Instruments of the Study}

To achieve the purpose of the study, the researcher developed two instruments: the writing comprehension test and the instructional program as follows:

\section{The Achievement Test}

The researcher designed the test to compare the achievements of the two groups on the pre and post tests to write a composition (see appendix C). It includes 3 topics based on the students' grades levels (low, average, and high) to write a perfect composition of 5 paragraghs about one of the copmposition types (process, describtive, and classification compositions).

The researcher followed a kind of validity based on analyzing content by asking a number of expert referees to judge the test for producing the final draft (see appendix E). The researcher used a rubric to correct the students' compositions based on the objectives of the test (see appendix D).

The test measured the students' ability to:

- Use unfamiliar words in writing composition.

Organize the composition perfectly according to the elements of writing composition.

- Adopt the mechanics of writing such as punctuation, capitalization, numbers and numerals, format and constraction.

- Use English appropriatly.

\section{The Instructional Program}


The researcher redesigned the Cornell card according to the concerned elements of composition writing and stages of writing. Cornell card is usually divided into three sections; the left column, the right one and the beneath section for summary. The researcher rebuilt the card to suite the elements of writing composition and the three stages of writing (pre-writing, while-writing, post-writing). While using the card in writing composition, several teqniques were used like: recording, questioning, reciting, reflecting, and reviewing. To summarize, the researcher suggested a new suggested Cornell card after redesighning the original one based on the stages of writing, elements of writing composition and number of classes. Appendix (B) is a model example that consists of one lesson about how to select a topic, how to write the first element of writing composition which is introductory paragrgh based on the three stages of writing.

The researcher used the content-method program to work out the validity of the program (see appendix E). He distributed the prepared program on experts to produce the final draft.

\section{E. Statistical Treatment}

The researchers used the T-test to find the differences between the two groups.

\section{F. The Procedures of the Study}

The researcher followed certain procedures to conduct the study:

- Reviewing the literature review (theoretical and practical studies).

- Selecting the sample of the study of male and female students who study EFL from Al-Balqa applied University.

- Designing the instruments of the study (test and instructional program) according to Cornell method and composition course.

- Establishing the validity and reliability of the instruments.

- Training the students and the lecturer in the experimental group on how to deal with the suggested Cornell proceadures in teaching and learning composition.

- Applying the pre-test in order to find out if the both groups (experimental and control) are equivilant then analysing the obtained data depending on the t-test.

- Applying the suggested Cornell method under study in the writing experimenat class and the traditional method of teaching composition in the writing control class

- Following the participants inside both classes.

- Applying the post-test for both groups (experimental and conventional) and gathering data by correcting all papers of the post-test then analysing the obtained data depending on the t-test.

- $\quad$ Discussing the results and suggesting recommendations.

\section{RESULTS AND DISCUSSION}

The study analyzed the data obtained from the pre0test to be sure that both groups are equivilant by using the following t-test in (table 1) below:

TABLE I.

T-TEST RESUlTS OF THE EXPERIMENTAL AND CONTROL GROUPS ON THE PRE-TEST OF WRITING COMPOSITION.

\begin{tabular}{|c|c|c|c|c|c|c|c|}
\hline & GROUP & $\mathrm{N}$ & Mean & Std. Deviation & $\mathrm{T}$ & Df & $\begin{array}{c}\text { Sig. (2- } \\
\text { tailed) }\end{array}$ \\
\hline \multirow{2}{*}{ PRE TEST } & Experimental & 30 & 38.57 & 5.341 & -.714 & 56 \\
\cline { 2 - 7 } & Control & 28 & 39.50 & 4.550 & & & \\
\end{tabular}

Before starting the experiment, table (1) showed that the difference between the mean scores of both groups on the pre test was not statistically significant $(\mathrm{t} \geq .005)$. Also, students' mean scores for both groups (38.57 and 39.50$)$ were almost equivalent in pre-test so both groups are equivalent

To find whether both groups have statistical significant difference on the pre test, t-test also conducted as follows:

TABLE II.

T-TEST RESULTS OF THE EXPERIMENTAL AND CONTROL GROUPS ON THE POST-TEST.

\begin{tabular}{|c|c|c|c|c|c|c|c|}
\hline & GROUP & $\mathrm{N}$ & Mean & Std. Deviation & $\mathrm{t}$ & Df & Sig. (2-tailed) \\
\hline \multirow[t]{2}{*}{ POST TEST } & Experimental & 30 & 44.80 & 4.180 & \multirow[t]{2}{*}{2.200} & \multirow[t]{2}{*}{56} & \multirow[t]{2}{*}{.032} \\
\hline & Control & 28 & 42.11 & 5.123 & & & \\
\hline
\end{tabular}

As shown above in table (2), there are statistical significant differences at $(\alpha \leq 0.05)$ between the means of both groups on the post-test of writing composition in favor of the experimental group. While looking through the mean scores in table 2, one notices that that the mean score of the experimental group (44.80) is higher that the mean score of control group (42.11) so students who learn composition by Cornell method showed higher levels of writing gains than those who learned by using the traditional method.

T-test showed that there was a statistical significant difference at $(\alpha \leq 0.05)$ between the mean scores of the 
experimental group and the control group on the post-test regarding writing composition. The difference was in favor of the experimental group which used Cornell method since the mean scores of Cornell group (44.80) was higher than the mean scores of the control group (42.11).

The positive effect of Cornell method on improving writing composition skills is expected because it has significant features and advantages. In Cornell method, the students can write the details belonged to the elements of the composition on the right side of the paper such as, writing details about the introduction and the body. On the left column (cue column), students can practise the pre-stage of writing through gathering information and details about their topics before while-writing stage and write the forgotten main ideas later while writing in the writing stage which tales place in the right column. Finally, the writers pratise post-writing in Cornell method through reviewing and editing the previous notes in the third section of Cornell card which is called "summary section".

Cornell method increases the students' knowledge and masters their information. Moreover, it motivates the students to focus on what they write and helps them remember. To summarize, this method helps the students to keep their writing organized then it makes connections to the information and revises to produce the final draft of composition.

There are no big differences between the mean scores of the experimental group and control group for several reasons. One reason related to the students who are unfamiliar with taking-note strategy in general and lack of Cornell method skills in particular. Rockler-Gladen (2007) claimed that many students lack note-taking skills so the researchers should train students how to deal with this method before applying their studies. Another reason goes to the fact that most of the students coudn't follow the speed of the instructor while teaching them writing accodring to Cornell method so they missed a lot of information which affected on their writing negatively.

Most of the related studies mentioned in the literature review (Jacobs, 2008; Zorn 2017 \&Baharev, 2016) found out positive effects of using Cornell method strategy on achievement of students. Also, (Davoudi, Moattarian \& Zareian 2015) showed that Cornell method has positive influence on learning grammar. For listening, (Rahmani \& Sadeghi, 2011 \&Hayati, 2009) showed significant differences in their studies while comparing Cornell method with the control methods in favor of Cornell method. Finally, the main finding of the study was in line with the findings of (Al-Ashkar, 2014) whose results provided evidence for the positive effect of using note-taking on improving writing skill. However, (Borr, et al., 2012) showed no significant difference in Cornell note-taking on student performance. He mentioned that there were several factors that had some bearing on the results such as the variation of learning styles among students and there was no way to determine if notes were actually used for studying.

\section{CONCLUSiOnS}

The purpose of the present study was to investigate the effects of suggested Cornell method on improving students' writing composition. The results of data analysis revealed that students who learnt composition by using the suggested Cornell method performed considerably better than did students who learnt through conventional method. The result of the currecnt study agreed with the previous related studies (Jacobs, 2008; Zorn 2017; Baharev ,2016; Davoudi, Moattarian \& Zareian, 2015; Rahmani \& Sadeghi, 2011 \&Hayati, 2009) which showed positive effects of using Cornell method on improving language skills and its components.

\section{RECOMMENDATIONS}

To apply Cornell method effectively inside the class, the lecturer should be slow in order to help students in writing. Also, the information shoud be also accurate because the Cornell method allows students to take notes in short form and reserve the left side for cues. Moreover, the study suggested to provide colleges and schools with enough materials to facilitate the use of Cornell method and minimize the large number of students in writing classes. Finally, the decision makers in the educational institution shoud hold workshops for training teachers or lecturers on how to teach the language skills according to Cornell method. 


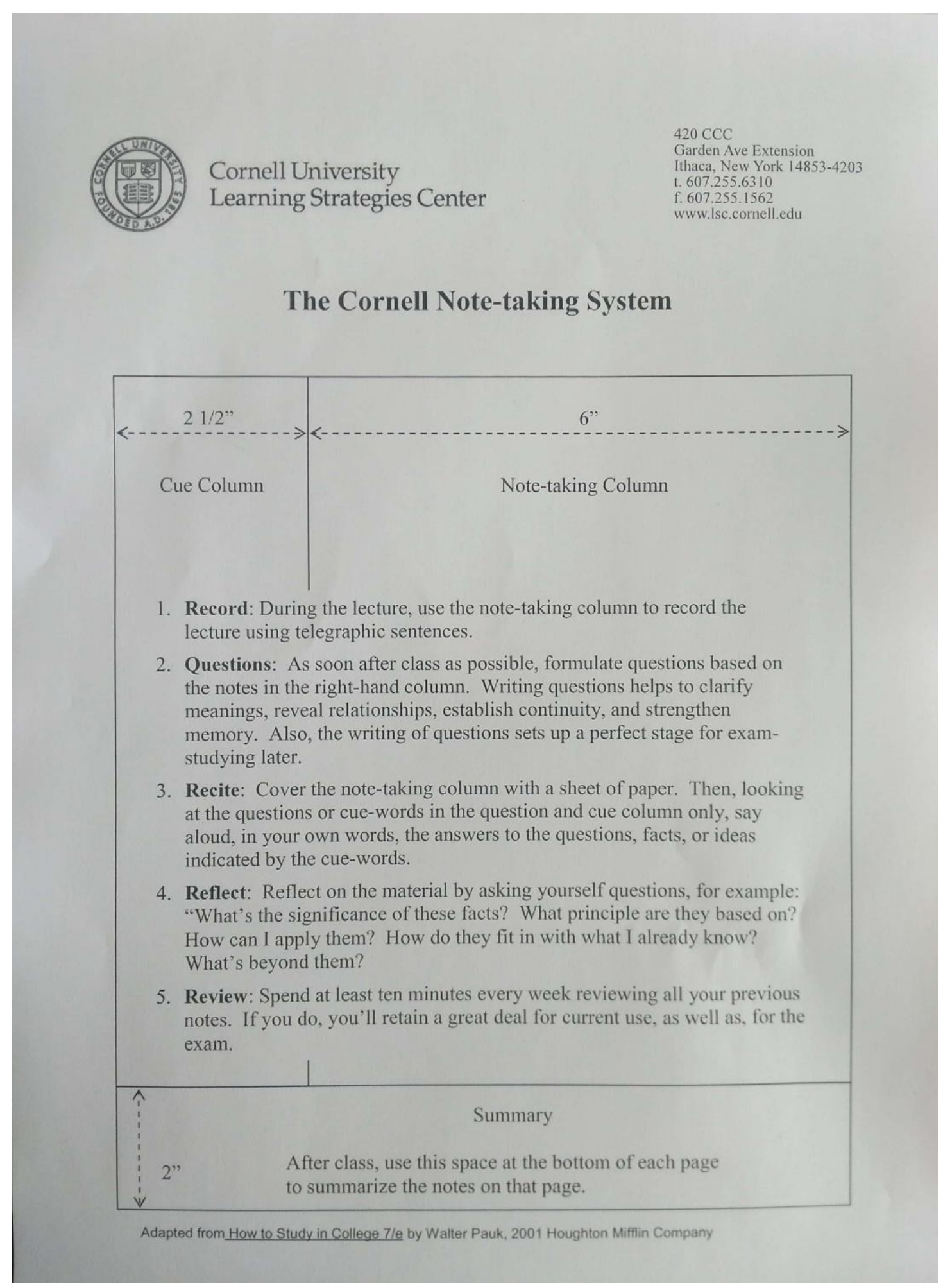

\section{APPENDiX B. SAMPle of LeSSON Plan}

\section{A. The main objective}

Students are expected to:

1. Select a process topic.

2. Write an introductory paragraph for a process composition.

B. Teaching and learning aids:

3. Cornell cards

4. pencils 
5. Pages for taking notes.

C. Period of time: two lectures

D. Procedures:

1. Preparation stage

- Students should carry all necessary items and materials to class such as notebook, planner, pens, pencils, Cornel cards, and small dictionary.

- The instructor meets their students to clarify concepts related to Cornell method and elements of writing composition.

- Students should begin taking notes for every lecture on a new card so the instructor prepares enough printed cards for the students to be used in all lectures.

2. Before writing stage:

- St should identify the chapter being covered at the top of the page, for example, process composition.

- Sts should discuss the topic with each other to be more familiar with the topic. They may use one of prewriting strategies like clustering, brainstorming and free writing.

- The students should determine a suitable topic to describe the sequence of steps in a procedure, for example: describing types of friends, changing a flat tire, studying for an exam etc....

- Students should use the top of Cornell cards to write their own selected topics.

- $\quad$ students should follow the instructor while discussion in the class.

- $\quad$ students should listen carefully and write the important instructions of the teacher in the right column of Cornell card (Note-taking column). The instructor directs the students through giving them pre-writing techniques to gather information about the topic in order to write the first element of writing composition (introductory paragraph).

- Students should rewrite the general ideas of the details to reconstruct the important elements of the writing by using the left side of their cards.

3. During writing stage:

- The instructor should use a large Cornell card to enable students following the steps of using Cornell method.

- Students should focus their attention on listening for any comments regarding the next lecture topic.

- Students should stay focused on what the instructor is saying.

- Students participate in class activities.

- Students have to use symbols and abbreviations whenever possible.

- Students should take too many notes. They can always omit unnecessary information later.

- Students should focus on the point the professor is making, rather than scrambling to copy the entire overhead without listening to what the professor is saying.

- Students write down notes in their own words when possible and think about what the professor is saying.

- Students add examples their professor provides in order to clarify abstract ideas and to jog their memory when studying later.

- Students should make eye contact with the lecturer.

- Students shouldn't be a clock-watcher.

4. After writing stage (evaluation section)

- Students read over the notes from the previous class at home.

- Students should review, revise, or edit the notes as soon as possible after the lecture by filling in the gap (summary section).

- Students should conduct short weekly review periods. Once a week, she goes through all her notes again and puts reviews on her calendar and makes it a habit.

- Students talk to the lecturer before the next lecture about any problems.

Note: In the next lecture, each student should use another card to start learning other elements of writing composition.

\section{APPENDix C. WRITING COMPOSITION TEST}

Write a composition of five paragraghs about one of the following topics:

1. The best way to loose weight.

2. How to quit smoking.

3. How to succeed in college.

\section{APPENDIX D. THE RUBRIC}

1. To write the introductory paragraph.

2. To write supporting paragraphs. 
3. To write the concluding paragraph.

4. To use correct grammar.

5. To not make spelling errors.

6. To use the suitable punctuations marks.

7. To establish coherence by using linking words.

8. To organize and order the composition.

9. To use suitable vocabularies.

10. To follow the composition format.

APPENDiX E. The List OF JURY FOR VALIDATING THE INSTRUMENT AND THE CIRC PROGRAM

\begin{tabular}{|c|c|c|c|}
\hline Name & Specialization & Affiliation & Academic position \\
\hline Ibrahim Al-Marzouk & $\begin{array}{l}\text { Curricula \& Methods of } \\
\text { TEFL }\end{array}$ & $\begin{array}{l}\text { Ministry of } \\
\text { education }\end{array}$ & Superviser \\
\hline Ahmed Al-Zu'bi & $\begin{array}{l}\text { Curricula \& Methods of } \\
\text { TEFL }\end{array}$ & $\begin{array}{l}\text { King saud } \\
\text { university }\end{array}$ & Assistant Professor \\
\hline Abd-Alruhman Bani-Melhim & Applied linguistics & $\begin{array}{l}\text { Al-Balqa Applied } \\
\text { University }\end{array}$ & Professor \\
\hline Murad Al-Kayed & Linguistics & $\begin{array}{l}\text { Al-Balqa Applied } \\
\text { University }\end{array}$ & Assistant Professor \\
\hline
\end{tabular}

\section{ACKNOWLEDGEMENTS}

The researcher would like to thank the deanship of scientific research in Al-Balqa Applied University who funded the current project and supported the researcher to achieve the study.

\section{REFERENCES}

[1] Al-Ashkar, B. (2014). The influence of note-taking strategy on improving students' academic achievement from English and TEFL majors' perspectives at An-Najah National University. Master degree. An-Najah National university

[2] Al-Nakkash, N. (1978). Different techniques for guided compositions. IDELTI Journal 10, 130-138.

[3] Baharev, Z. (2016). The effects of Cornell note-taking and review strategies on recall and comprehension of lecture content for middle school students with and without disabilities. Ph.D. dissertation. The Graduate School of Education, Rutgers, The State University of New Jersey.

[4] Bani-yasain, M. (2010). The language. Jordan, Irbid: Hamada Company.

[5] Borr, M.; Duffield, S; Napoleon, L. \& Welch, A. (2012). The Impact of the Cornell Note-Taking Method on Students' Performance in a High School Family and Consumer Sciences Class. Journal of Family \& Consumer Sciences Education 30.1, 27-38.

[6] Chaudron, C., Loschky, L., \& Cook, J. (1994). Second language listening comprehension and lecture note-taking. In J. Flowerdew (Ed.), Academic listening: Research perspectives. Cambridge: Cambridge University Press.

[7] Clerehan, R. (1995). Taking it down: Note-taking practices of L1 and L2 students. English for specific purposes 14.2, 137-157.

[8] Daniels, P. \& Bright, W. (1996). The world's writing systems. Oxford: Oxford University Press.

[9] Davoudi M; Moattarian N. \& Zareian G. (2015). Impact of Cornell note-taking method instruction on grammar learning of Iranian EFL learners. Journal of Studies in Education 5.2, 252-265.

[10] Fahmy, J.J. \& Bilton, L. (1991). Listening and note-taking in higher education. In S. Anivan (Ed.), Language teaching methodology for the nineties. Singapore: SEAMO Regional Language Centre.

[11] Hayati, M. (2009). The impact of note-taking strategies on listening comprehension of EFL learners. English language Teaching 2.1, 101-111.

[12] Jacobs K. (2008). A Comparison of Two Note Taking Methods in a Secondary English Classroom. Proceedings of the 4th Annual GRASP Symposium, Wichita State University.

[13] Lieberman, D.A. (2000). Learning: Behavior and cognition. Belmont, CA: Wadsworth.

[14] Nunan, D. (2003). Practical English language teaching. New York, NY: McGraw-Hill.

[15] Pauk, W., \& Owens, R. J. Q., (2011). How to study in college. Boston, MA: Wadsworth, Cengage Learning.

[16] Rahmani, M.\& Sadeghi, K. (2011). Effects of note-taking training on reading comprehension and recall. The Reading Matrix $11.2,116-128$.

[17] Williams, G. T. D. (2004). Assessment of 8th grade students' attitudes and perceptions of Cornell's note-taking. Ph.D. dissertation, Union University.

[18] Zorn, D. (2007). Increasing Achievement Scores with the Use of the Cornell Note-taking Style. Master degree. Hiritage College.

Mohammad A. Alzu'bi is associate professor in Albalqa Applied University in Jordan and got his PhD in Applied LinguisticsTEFL and curricula. His main research interests lie in the four skills, grammar and vocabularies' strategies, second language acquisition and learning, translation, CALL, TEFL, and TESL. Also he is expert in analyzing and designing curricula for primary and 
secondary stages at schools. He has published several researches and attended several conferences. Finally, he is awarded as one of the best researchers at Albalqa Applied University. 